Vol. 23, No. 2, September 2020, hlm. 94-104

p-ISSN: 1410-9344; e-ISSN: 2549-5631

homepage: http://journals.ums.ac.id/index.php/warta

\title{
Pendampingan Pelaksanaan Survey Kepuasan Pelanggan Pada Coffee Shop Cekopi di Mendungan, Kartasura
}

\author{
Salman Faris Insani, Ariyani Wahyu Wijayanti, Bambang Nur Cahyaningrum \\ Program Studi Manajemen, Fakultas Ekonomi \\ Universitas Veteran Bangun Nusantara \\ email: faris.uvbn@gmail.com
}

\section{Article Info}

Submitted: 21 November 2019

Revised: 6 January 2020

Accepted: 20 March 2020

Published: 7 April 2020

Keywords : customer, satisfaction, survey, Cekopi

\begin{abstract}
Cekopi is a small and medium enterprises that engages in the coffee shop business. Based on the sales data, this coffee shop are experiencing sales fluctuations in 2018. It is fueled by the competition between the coffee shop that is increasingly fierce. Strategies that selected to address these conditions is by commited to improving good relations with customers by doing customer satisfaction survey. Through this strategy, Cekopi hopes to explore needs, desires, and behaviors of their customers as the basis for the business development in the future. Until this time, Cekopi don't have any knowledge that is sufficiently in the implementation of customer satisfaction survey. This is because they never carried out these activities before. We can concluded that the implementation of the research market through customer satisfaction survey with a decent structur and documentation is a crucial matter for cekopi. To answer this problems, we organize the implementation assistance for customer satisfaction survey that implemented in six phases, namely: concept socialization of customer satisfaction survey, questionnaires design, sampling procedures design, data preparation, results interpretation, and preparation to archives or documentation from customer satisfaction survey activities. As the result, based on the evaluation of activities that have been carried out, it is known that at each stage of the activity in the posttest score increased $\geq 25 \%$ from the pretest score. The results indicate that SME partners have increased knowledge in terms of conducting customer satisfaction surveys and archiving the results of customer satisfaction survey. The output of this activity is the customer satisfaction survey report of the Cekopi coffee shop in 2019. Based on the measured indicators, it can be concluded that the assistance, counseling, and customer satisfaction survey training activities for Cekopi's coffee shop SME partners have been declared successful.
\end{abstract}


Kata kunci: survey, kepuasan, pelanggan, Cekopi

\section{Abstrak}

Cekopi adalah usaha kecil dan menengah yang bergerak di bidang bisnis coffee shop. Berdasarkan data penjualan, diperoleh informasi bahwa kedai kopi tersebut mengalami fluktuasi penjualan pada tahun 2018. Hal ini dipicu oleh adanya persaingan antar coffee shop yang semakin sengit. Strategi yang dipilih cekopi untuk menyikapi kondisi tersebut adalah dengan berkomitmen untuk meningkatkan hubungan baik dengan pelanggan. Strategi yang mereka pilih untuk mengelola hubungan pelanggan adalah dengan melakukan riset pasar melalui survey kepuasan pelanggan. Melalui survey kepuasan pelanggan, cekopi berharap dapat menggali kebutuhan, keinginan, dan perilaku pelanggan sebagai dasar untuk pengembangan bisnis mereka di masa mendatang. Hingga saat ini, cekopi belum memiliki pengetahuan yang cukup terkait dengan pelaksanaan survey kepuasan pelanggan. Hal ini dikarenakan cekopi belum pernah melaksanakan kegiatan tersebut sebelumnya. Dapat disimpulkan bahwa pelaksanaan riset pasar melalui survey kepuasan pelanggan yang terstruktur dan terdokumentasi dengan baik saat ini merupakan hal krusial bagi cekopi. Untuk menjawab permasalahan tersebut, Tim PKM Universitas Veteran Bangun Nusantara Sukoharjo menyelenggarakan kegiatan pendampingan pelaksanaan survey kepuasan pelanggan yang dilaksanakan dalam enam tahap, yaitu: sosialisasi konsep survey kepuasan pelanggan, merancang kuesioner dan format, merancang prosedur sampling, menyiapkan data, menginterpretasikan hasil survey, serta penyusunan arsip atau dokumentasi kegiatan survey kepuasan pelanggan. Berdasarkan evaluasi kegiatan yang telah dilakukan, diketahui bahwa pada masing-masing tahapan kegiatan skor posttest mengalami peningkatan $\geq 25 \%$ dari pada skor pretest. Hasil ini menunjukkan mitra UMKM mengalami peningkatan pengetahuan dalam hal pelaksanaan survey kepuasan pelanggan dan pengarsipan hasil kegiatan survey kepuasan pelanggan. Luaran dari kegiatan ini adalah laporan survey kepuasan pelanggan UMKM coffee shop Cekopi tahun 2019. Berdasarkan indikator yang telah diukur, dapat disimpulkan bahwa kegiatan pendampingan, penyuluhan, dan pelatihan survey kepuasan pelanggan untuk mitra UMKM coffee shop Cekopi dinyatakan berhasil.

\section{PENDAHULUAN}

Cekopi adalah UMKM (Usaha Mikro, Kecil, dan Menengah) yang bergerak di bidang bisnis coffee shop. Cekopi didirikan oleh Surya Kusuma Raharjo, SH pada tahun 2008 dan merupakan salah satu pelopor warung kopi di Solo Raya (Kumalaningrum et al., 2016). Kedai kopi ini memegang jargon "Support our local coffee" sebagai bentuk dukungan terhadap kesejahteraan petani kopi lokal di Indonesia. Cekopi terletak di Jalan Mendungan No. 13, Pabelan, Kartasura, Sukoharjo (Wibowo, 2018).
Keberadaan Cekopi bermanfaat bagi masyarakat sekitar karena berkontribusi dalam menyerap tenaga kerja setempat baik sebagai pegawai maupun pengelola lahan parkir. Coffee shop ini beroperasi mulai dari jam 17:00 sampai dengan 24:00 WIB dan menawarkan beragam kopi dengan harga terjangkau (Astutik, 2018). Jenis kopi yang ditawarkan diantaranya adalah kopi Nusantara Aceh Gayo, Bogowongso Ronusta, Ciwidey, Bali Kintamani, Flores Bajawa, Toraja Kalori, Kopi susu Cekopi, serta Kopi Vietnam Drip. Selain itu, coffee shop ini juga menyediakan 
variasi dari minuman kopi seperti White Coffee, Signature, Coffee Blend, Chocolate, Tes Other Wilshake, serta Manual Breaking Methd (Ariyanto, 2019).

Berdasarkan hasil wawancara pendahuluan yang dilakukan oleh tim pengabdian masyarakat terhadap Bapak Surya selaku owner dari cekopi, diperoleh informasi bahwa Cekopi menyasar pangsa pasar mahasiswa dan pegawai swasta di surakarta dan sekitarnya. Mahasiswa dipilih karena kegiatan mereka yang cenderung banyak menghabiskan waktu di luar ruangan seperti halnya mengerjakan tugas kelompok atau hanya sekedar bersantai bersama teman-temannya dalam menghabiskan waktu. Pegawai swasta dipilih karena lebih sering meeting secara informal dengan memanfatkan coffee shop sebagai tempat bertemu relasinya. Informasi ini diperoleh berdasarkan riset pasar yang telah dilakukan oleh Cekopi untuk mengetahui latar belakang dari konsumen potensialnya. Akan tetapi, riset pasar yang dilakukan pada tahun 2010 tersebut tidak tersusun secara sistematis. Riset pasar hanya dilakukan dengan cara melakukan interaksi atau berbincang-bincang langsung dengan konsumen dan berdiskusi dengan sesama pemilik warung kopi, lalu mengambil kesimpulan dari target potensial.

Hasil riset pasar tersebut disimpulkan berdasarkan sharing pengalaman sesama kru di cekopi saat mengamati kedai kopi kompetitor atau saat outlet Cekopi sedang sepi pengunjung. Selain itu, data dan informasi pendukung juga didapat dari hasil observasi dan diskusi bersama para pemilik usaha kedai kopi yang ada di solo raya. Data-data yang dimiliki kemudian dibahas dan menjadi dasar penentuan target potensial dari cekopi yaitu kalangan mahasiswa dan pegawai swasta di surakarta dan sekitarnya. Saat tim pengabdian masyarakat mencoba untuk meminta laporan atau arsip dari kegiatan tersebut, informan menyatakan tidak memilikinya dengan alasan Cekopi belum pernah membuat laporan tersebut. Beliau hanya mengandalkan ingatan dan asumsi dari kru Cekopi sendiri terkait dengan hasil riset pasar tersebut. Dapat disimpulkan bahwa kegiatan riset pasar yang dilakukan di cekopi belum terstruktur dan terdokumentasikan dengan baik.
Tabel 1. Data penjualan cekopi januari desember 2018

\begin{tabular}{llrr}
\hline No. & Bulan & $\begin{array}{c}\text { Penjualan } \\
\text { (Rp) }\end{array}$ & $\begin{array}{c}\text { Kenaikan/ } \\
\text { Penurunan } \\
\text { (Rp) }\end{array}$ \\
\hline 1. & Januari & 37.000 .000 & - \\
\hline 2. & Februari & 33.000 .000 & -4.000 .000 \\
\hline 3. & Maret & 38.000 .000 & 5.000 .000 \\
\hline 4. & April & 35.000 .000 & -3.000 .000 \\
\hline 5. & Mei & 36.000 .000 & 1.000 .000 \\
\hline 6. & Juni & 32.000 .000 & -4.000 .000 \\
\hline 7. & Juli & 39.000 .000 & 7.000 .000 \\
\hline 8. & Agustus & 35.000 .000 & -4.000 .000 \\
\hline 9. & September & 33.000 .000 & -2.000 .000 \\
\hline 10. & Oktober & 30.000 .000 & -3.000 .000 \\
\hline 11. & November & 30.000 .000 & - \\
\hline 12. & Desember & 35.000 .000 & 5.000 .000 \\
\hline & &
\end{tabular}

Sumber: Cekopi, 2019

Berdasarkan data penjualan cekopi, diperoleh informasi bahwa kedai kopi tersebut mengalami fluktuasi penjualan pada tahun 2018. Hal ini dipicu oleh adanya persaingan antar coffee shop yang semakin sengit dalam satu tahun terakhir. Kondisi ini berbeda dengan tahun-tahun sebelumnya yang menunjukkan adanya trend kenaikan penjualan yang relatif baik. Data penjualan dari cekopi periode Januari - Desember 2018 disajikan pada tabel 1.

Berdasarkan data pada tabel 1, dapat dilihat bahwa Cekopi mengalami fluktuasi penjualan. Bisa dilihat dari tabel di atas bahwa pada bulan januari sampai bulan juni mengalami kenaikan dan penurunan penjualan. Pada bulan juli mengalami kenaikan penjualan yang tertinggi yaitu Rp 7.000.000. Pada bulan agustus, september dan oktober mengalami penurunan penjualan. Sedangkan pada bulan november terjadi stagnan dan pada bulan desember kembali mengalami kenaikan penjualan.

Menyikapi kondisi fluktuasi penjualan tersebut, cekopi berkomitmen untuk lebih menjaga dan meningkatkan hubungan baik dengan pelanggan. Hal ini dikarenakan Cekopi semakin menyadari pentingnya keberadaan pelanggan bagi kelangsungan bisnis mereka. Kebijakan ini dinilai tepat mengingat 
pengelolaan hubungan pelanggan (customer relationship management) merupakan salah satu faktor penting untuk memaksimalkan loyalitas pelanggan (Munandar, 2016). Strategi yang mereka pilih untuk mengelola hubungan pelanggan adalah dengan melakukan riset pasar melalui survey kepuasan pelanggan. Melalui survey kepuasan pelanggan, cekopi berharap dapat menggali kebutuhan, keinginan, dan perilaku pelanggan sebagai dasar untuk pengembangan bisnis mereka di masa mendatang.

Literatur di bidang manajemen pemasaran menyatakan bahwa pelanggan merupakan komponen lingkungan yang mampu mempengaruhi pencapaian tujuan perusahaan. Pencapaian tujuan perusahaan tergantung pada seberapa mampu perusahaan tersebut memahami dan memenuhi kebutuhan pelanggan (Kotler \& Armstrong, 2014). Salah satu cara untuk memahami kebutuhan pelanggan adalah dengan memperhatikan kepuasan pelanggan. Kepuasan pelanggan ditandai oleh adanya perilaku pembelian ulang sebuah produk yang berdampak positif pada tingkat penjualan perusahaan. Pelanggan yang tidak puas akan menunjukkan gejala sebaliknya. Pelanggan yang tidak puas akan menceritakan ketidakpuasannya kepada orang lain. Hal ini akan berdampak negatif bagi perusahaan dan mempengaruhi tingkat penjualan mereka (Kotler \& Keller, 2016).

Perusahaan dapat melakukan survey untuk mengidentifikasi tingkat kepuasan pelanggan. Metoda survey menggunakan kuesioner yang terstruktur dan diberikan kepada responden dengan tujuan untuk mendapatkan informasi spesifik (Sekaran \& Bougie, 2017). Metoda ini memperoleh informasi berdasarkan pertanyaan yang diajukan ke responden. Responden ditanya mengenai berbagai pertanyaan yang terkait dengan perilaku, maksud, pengetahuan, motivasi, serta karakteristik demografis dan gaya hidup mereka. Pertanyaan bisa diajukan secara verbal, dalam bentuk tertulis, atau melalui komputer, dan tanggapan dapat diperoleh dari salah satu bentuk tersebut (Sugiyono, 2017).

Metoda survey dapat dipilih karena mempunyai beberapa kelebihan. Pertama, kuesioner relatif mudah untuk dikelola. Kedua, data yang diperoleh dapat dipercaya, karena tanggapan terbatas pada alternative yang dinyatakan. Penggunaan pertanyaan dengan tanggapan dapat mengurangi variabilitas hasil yang mungkin disebabkan oleh pewawancara yang berbeda. Akhirnya, penetapan kode, analisis, dan interpretasi data nya juga relatif sederhana (Ferdinand, 2014).

Hingga saat ini, cekopi belum memiliki pengetahuan yang cukup terkait dengan pelaksanaan survey kepuasan pelanggan. Hal ini dikarenakan cekopi belum pernah melaksanakan kegiatan tersebut sebelumnya. Dapat disimpulkan bahwa pelaksanaan riset pasar melalui survey kepuasan pelanggan yang terstruktur dan terdokumentasi dengan baik saat ini merupakan hal krusial bagi cekopi.

Berdasarkan analisis situasi yang telah dijabarkan, masalah yang teridentifikasi pada mitra UMKM coffee shop Cekopi antara lain: mitra belum memiliki pengetahuan mendalam mengenai pelaksanaan survey kepuasan pelanggan yang terstruktur dan pengarsipan hasil kegiatan survey kepuasan pelanggan. Berdasarkan uraian tersebut, kegiatan pendampingan pelaksanaan survey kepuasan pelanggan ini bertujuan untuk meningkatkan pengetahuan dan pemahaman mitra UMKM mengenai pelaksanaan survey kepuasan pelanggan yang terstruktur dan terdokumentasi dengan baik. Dengan demikian, kegiatan ini dapat menghasilkan produk berupa laporan survey kepuasan pelanggan yang dapat dimanfaatkan oleh mitra UMKM untuk mendukung pengambilan keputusan bisnis.

\section{METODE}

Untuk menjawab permasalahan yang ada pada Mitra UMKM, Tim PKM Universitas Veteran Bangun Nusantara Sukoharjo menjalin kerjasama dengan coffee shop Cekopi untuk memecahkan masalah yang dihadapi. Adapun metode yang digunakan dalam pelaksanaan kegiatan pengabdian ini meliputi langkahlangkah yang disajikan pada gambar 1 sebagai berikut:

Warta LPM, Vol. 23, No. 2, September 2020 


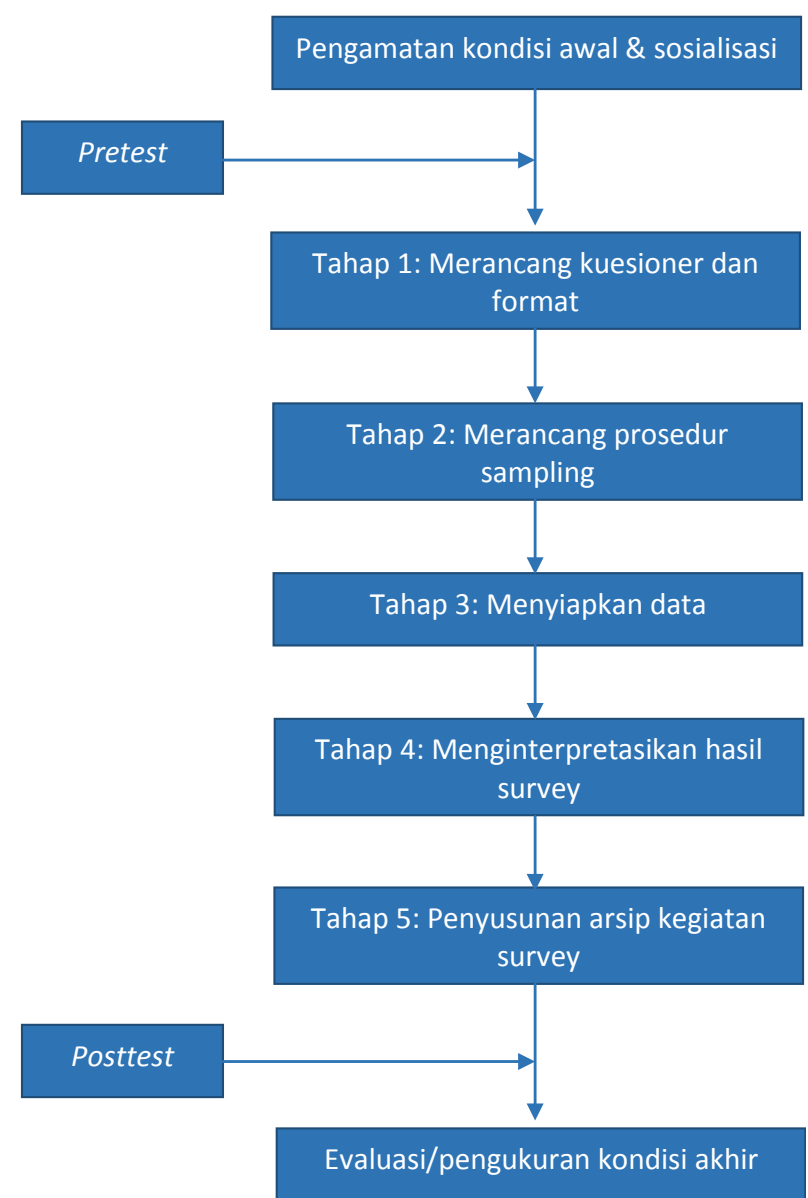

Gambar 1. Metode pelaksanaan kegiatan

Secara lebih detil, metode pelaksanaan kegiatan pengabdian masyarakatini berdasarkan gambar 1 di atas dapat diuraikan sebagai berikut:

a. Sosialisasi konsep survey kepuasan pelanggan, kegiatan ini dilaksanakan dengan cara memberikan gambaran umum kepada Mitra UMKM terkait dengan konsep, manfaat, serta tahapan dalam praktik survey kepuasan pelanggan yang terstruktur dan sesuai dengan kaidah metoda penelitian bisnis. Tujuan dari kegiatan ini adalah Mitra UMKM memiliki pengetahuan dasar tentang konsep, manfaat, serta tahapan dalam praktik survey kepuasan pelanggan yang terstruktur dan terdokumentasi dengan baik.

b. Merancang kuesioner dan format, kegiatan ini dilaksanakan dengan cara melatih Mitra UMKM untuk menentukan secara spesifik informasi yang dibutuhkan, menentukan susunan kata dari pertanyaan, dan mengidentifikasi formulir dan layout.
Tahapan ini diawali dengan diskusi intensif dengan mitra pengabdian untuk menentukan jenis informasi yang akan digali dari pelanggan. Tujuan dari kegiatan ini adalah Mitra UMKM memperoleh gambaran terkait dengan perancangan kuesioner dan format yang sesuai dengan kebutuhan.

c. Merancang prosedur sampling, kegiatan ini dilaksanakan dengan cara melatih Mitra UMKM untuk mendefinisikan populasi sasaran, menentukan sampel, memilih teknik sampling, menentukan jumlah sampel, dan melaksanakan proses sampling. Tujuan dari kegiatan ini adalah Mitra UMKM memperoleh gambaran terkait dengan prosedur sampling dan mampu mempraktikkan prosedur tersebut.

d. Menyiapkan data, kegiatan ini dilaksanakan dengan cara melatih Mitra UMKM untuk melakukanpemeriksaanterhadapkuesioner yang telah diisi oleh responden, melakukan pengkodean, melakukan entry data, dan analisis data menggunakan software SPSS for windows. Tujuan dari kegiatan ini adalah Mitra UMKM memperoleh pengetahuan dan mampu mempraktikkan pemeriksaan kuesioner yang telah diisi oleh responden, melakukan pengkodean, entry data, dan analisis data.

e. Menginterpretasikan hasil survey, kegiatan ini dilaksanakan dengan cara melatih Mitra UMKM untuk mengevaluasi hasil akhir analisis data berupa karakteristik responden dan hasil distribusi frekuensi yang diperoleh dari software SPSS for windows, dan juga melakukan rekap terhadap jawaban dari pertanyaan terbuka. Tujuan dari kegiatan ini adalah Mitra UMKM memperoleh pengetahuan dan mampu mengevaluasi secara mandiri hasil akhir analisis data berupa karakteristik responden dan hasil distribusi frekuensi yang diperoleh dari software SPSS for windows, serta mampu melakukan rekap terhadap jawaban dari pertanyaan terbuka.

f. Penyusunan arsip atau dokumentasi kegiatan survey kepuasan pelanggan, kegiatan ini dilaksanakan dengan cara melatih Mitra UMKM untuk melakukan 
penyusunan arsip atau dokumentasi kegiatan survey kepuasan pelanggan dan menghasilkan laporan kegiatan survey kepuasan pelanggan. Tujuan dari kegiatan ini adalah Mitra UMKM memperoleh pengetahuan dan mampu menyusun arsip atau dokumentasi kegiatan survey kepuasan pelanggan sehingga dapat menghasilkan laporan kegiatan survey kepuasan pelanggan secara mandiri.

Keenam kegiatan tersebut diharapkan dapat terlaksana dengan baik dalam jangka waktu tiga bulan (juni 2019 - agustus 2019). Masing-masing tahapan dalam kegiatan tersebut memiliki durasi waktu $\pm 1 \times 90$ menit. Lokasi yang disepakati oleh pihak tim pengabdian masyarakat dengan pengelola cekopi untuk pelaksanaan kegiatan adalah di coffee shop cekopi mendungan kartasura. Kegiatan ini diharapkan dapat diikuti oleh 10 orang peserta, yang mewakili keseluruhan dari karyawan coffee shop Cekopi.

Pelaksanaan kegiatan pelatihan dilakukan dalam bentuk penyampaian tutorial dan melakukan praktek secara langsung. Tutorial disampaikan secara oral oleh pemateri dan peserta menjalankan praktek sesuai instruksi yang disampaikan oleh pemateri. Apabila terdapat kendala saat proses berlangsung, peserta dapat langsung menanyakan kepada pemateri tanpa harus menunggu sesi materi selesai. Penyampaian materi menggunakan teknik seperti ini disebut dengan metode pembelajaran aktif (active learning) (Kristin, 2017). Pemilihan metode ini menurut Sukirman, dkk. (2019) berpotensi mendorong peserta untuk berani mengungkapkan pikiran, keinginan, dan hal-hal lain yang mungkin tidak diketahui sehingga menjadikan suasana kegiatan menjadi lebih menarik.

Evaluasi terhadap keberhasilan metode pelaksanaan kegiatan diketahui dari adanya peningkatan pengetahuan dan kemampuan peserta mitra terhadap teori dan praktek yang telah diberikan. Evaluasi dilaksanakan melalui dualangkah menggunakaninstrumen pertanyaan kuesioner. Langkah pertama, sebelum seluruh tahapan kegiatan dilaksanakan, diadakan test pendahuluan untuk mengetahui seberapa jauh pemahaman awal dari peserta mitra terhadap bahan materi yang akan disampaikan (pretest). Langkah kedua, diadakan test atau evaluasi tertulis setelah pelaksanaan kegiatan dari keseluruhan tahapan selesai (posttest). Evaluasi terhadap indikator keberhasilan dari keseluruhan tahapan kegiatan, bila skor posttest mengalami peningkatan $\geq 25 \%$ dari pada skor pretest. Pengisian kuesioner dilakukan secara tertulis dengan menggunakan skala interval 1 sampai dengan 10 (Sekaran \& Bougie, 2017). Nilai 1 menyatakan sangat tidak mengetahui sedangkan nilai 10 mewakili pernyataan sangat mengetahui. Adapun instrumen pertanyaan kuesioner pretest dan posttest disajikan dalam tabel 2 .

Tahap evaluasi merupakan bagian akhir sebelum penarikan kesimpulan. Tahap ini dilaksanakan untuk mengetahui sejauh mana kegiatan dapat bermanfaat, sehingga dapat digunakan sebagai pedoman untuk pelaksanaan kegiatan sejenis berikutnya. Apabila terdapat kekurangan bisa ditambahkan dan apabila

Tabel 2. Kuesioner pretest dan posttest

\begin{tabular}{cl}
\hline No. & \multicolumn{3}{c}{ Pertanyaan } \\
\hline 1. & $\begin{array}{l}\text { Saya mengetahui tahapan yang harus } \\
\text { dilaksanakan dalam praktik survey } \\
\text { kepuasan pelanggan. }\end{array}$ \\
\hline 2. & Saya mengetahui cara untuk merancang \\
kuesioner sesuai dengan format yang \\
dibutuhkan dalam praktik survey \\
kepuasan pelanggan.
\end{tabular}

3. Saya mengetahui cara untuk merancang prosedur sampling sesuai dengan kebutuhan dalam praktik survey kepuasan pelanggan.

4. Saya mengetahui cara untuk melakukan analisis data menggunakan software SPSS for windows dalam praktik survey kepuasan pelanggan.

5. Saya mengetahui cara untuk mengevaluasi hasil analisis data dari software SPSS for windows dalam praktik survey kepuasan pelanggan.

6. Secara keseluruhan, saya mengetahui cara untuk membuat laporan kegiatan survey kepuasan pelanggan secara mandiri.

Warta LPM, Vol. 23, No. 2, September 2020 
terdapat kelebihan bisa diadopsi untuk kegiatan berikutnya. Hasil kuesioner pretest dan posttest dalam tahap evaluasi diolah dan disajikan dalam bentuk grafik yang dilengkapi dengan uraian secara deskriptif. Dengan demikian, kesimpulan yang dibuat menjadi lebih mudah disampaikan guna memberikan rekomendasi pelaksanaan berikutnya.

\section{HASIL DAN PEMBAHASAN}

Sesuai dengan desain kegiatan yang sudah dirancang dalam enam tahapan, kegiatan pelatihan dilaksanakan dalam jangka waktu tiga bulan (Juni 2019 - Agustus 2019). Lokasi yang disepakati oleh pihak tim pengabdian masyarakat dengan pengelola cekopi untuk pelaksanaan kegiatan adalah di coffee shop cekopi mendungan kartasura. Keseluruhan kegiatan diikuti oleh 10 orang peserta, yang mewakili keseluruhan dari karyawan coffee shop Cekopi.

Kegiatan pertama adalah sosialisasi konsep survey kepuasan pelanggan yang diselenggarakan pada tanggal 10 juni 2019. Kegiatan ini dilaksanakan dengan cara memberikan gambaran umum kepada Mitra UMKM terkait dengan konsep, manfaat, serta tahapan dalam praktik survey kepuasan pelanggan yang terstruktur dan sesuai dengan kaidah metoda penelitian bisnis. Gambar 2 menunjukkan salah satu suasana kegiatan ketika tahap sosialisasi konsep survey kepuasan pelanggan dilaksanakan.

Setelah tahap sosialisasi dilaksanakan, kuesioner pretest dibagikan kepada 10 peserta secara langsung. Hasil kuesioner pretest disajikan pada tabel 3 .

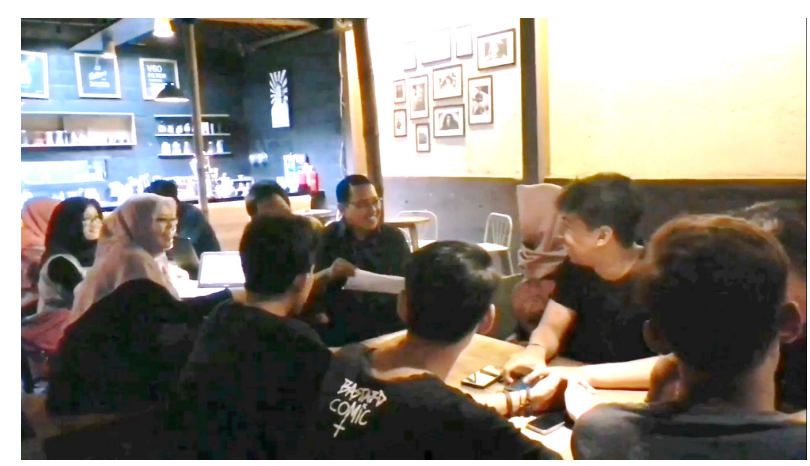

Gambar 2. Salah satu suasana kegiatan ketika tahap sosialisasi konsep survey kepuasan pelanggan dilaksanakan.

Warta LPM, Vol. 23, No. 2, September 2020
Tabel 3. Respon peserta sebelum pelatihan (pretest)

\begin{tabular}{ccccccc}
\hline \multirow{2}{*}{$\begin{array}{c}\text { Responden } \\
\text { (R) }\end{array}$} & \multicolumn{6}{c}{ Pertanyaan } \\
\cline { 2 - 7 } & P1 & P2 & P3 & P4 & P5 & P6 \\
\hline R1 & 4 & 5 & 3 & 2 & 2 & 3 \\
\hline R2 & 3 & 3 & 2 & 1 & 1 & 2 \\
\hline R3 & 3 & 3 & 2 & 1 & 1 & 2 \\
\hline R4 & 2 & 2 & 1 & 1 & 1 & 2 \\
\hline R5 & 4 & 5 & 3 & 1 & 1 & 2 \\
\hline R6 & 2 & 2 & 2 & 1 & 1 & 2 \\
\hline R7 & 4 & 5 & 2 & 1 & 1 & 2 \\
\hline R8 & 3 & 3 & 2 & 1 & 1 & 2 \\
\hline R9 & 3 & 5 & 2 & 1 & 1 & 2 \\
\hline R10 & 2 & 2 & 1 & 1 & 1 & 2 \\
\hline & & & & & &
\end{tabular}

Sebanyak 10 peserta mengisi kuesioner berdasarkan pertanyaan yang tersaji pada tabel 2 dengan rentang skor jawaban 1-10. Terlihat bahwa tidak ada satu pun responden yang menjawab dengan nilai mendekati 10 . Nilai tertinggi hanya 5 , yaitu pada pertanyaan kedua sebanyak 4 orang. Hal ini berarti bahwa pengetahuan peserta tentang praktik survey kepuasan pelanggan relatif minim. Artinya, sebagian besar peserta masih memiliki pengetahuan yang terbatas terkait dengan tahapan dalam survey kepuasan pelanggan yang terdiri dari merancang kuesioner, merancang prosedur sampling, melakukan analisis data, dan mengevaluasi hasil analisis data menggunakan software SPSS for windows. Selain itu, para peserta juga belum memiliki pengetahuan yang cukup terkait dengan cara untuk membuat laporan kegiatan survey kepuasan pelanggan secara mandiri.

Setelahtahapsosialisasidan $p r e t e s t$, kegiatan yang kedua adalah merancang kuesioner dan format. Kegiatan ini dilaksanakan pada tanggal 25 juni 2019. Kegiatan ini dilaksanakan dengan cara melatih Mitra UMKM untuk menentukan secara spesifik informasi yang dibutuhkan, menentukan susunan kata dari pertanyaan, dan mengidentifikasi formulir dan layout. Hasil dari tahapan ini berupa sejumlah indikator yang digunakan untuk mengukur persepsi pelanggan terhadap kualitas pelayanan dari pegawai cekopi, persepsi pelanggan terhadap kualitas fisik (yang terdiri dari: makanan, minuman, serta interior) 
di cekopi, persepsi terhadap harga yang harus dibayarkan ketika mengunjungi cekopi, serta tingkat kepuasan pelanggan cekopi.

Tahapan ketiga yaitu merancang prosedur sampling. Kegiatan ini dilaksanakan pada tanggal 11 juli 2019. Kegiatan ini dilaksanakan dengan cara melatih Mitra UMKM untuk mendefinisikan populasi sasaran, menentukan sampel, memilih teknik sampling, menentukan jumlah sampel, dan melaksanakan proses sampling.

Tahapan keempat adalah menyiapkan data. Kegiatan ini dilaksanakan pada tanggal 23 juli 2019. Kegiatan ini dilaksanakan dengan cara melatih Mitra UMKM untuk melakukan pemeriksaan terhadap kuesioner yang telah diisi oleh responden, melakukan pengkodean, melakukan entry data, dan analisis data menggunakan software SPSS for windows.

Tahapan kelima yaitu menginterpretasikan hasil survey. Kegiatan ini dilaksanakan pada tanggal 5 Agustus 2019. Pelaksanaan kegiatan ini adalah dengan melatih Mitra UMKM untuk mengevaluasi hasil akhir analisis data berupa karakteristik responden dan hasil distribusi frekuensi yang diperoleh dari software SPSS for windows, dan juga melakukan rekap terhadap jawaban dari pertanyaan terbuka.

Tahapan terakhir adalah penyusunan arsip atau dokumentasi kegiatan survey kepuasan pelanggan yang dilaksanakan pada tanggal 8 Agustus 2019. kegiatan ini dilaksanakan dengan cara melatih Mitra UMKM untuk melakukan penyusunan arsip atau dokumentasi kegiatan survey kepuasan pelanggan dan menghasilkan laporan kegiatan survey kepuasan pelanggan.

Setelah seluruh kegiatan selesai terlaksana, peserta diwajibkan mengisi kuesioner sama seperti dengan pertanyaan sebelum mengikuti pelatihan, yaitu seperti yang disajikan pada tabel 2. Adapun hasil kuesioner posttest disajikan pada tabel 4 .

Perbandingan hasil tanggapan peserta antara sebelum dan sesudah kegiatan yang diolah dalam persentase tersaji dalam bentuk diagram batang pada gambar 3. Diperoleh nilai sebesar 30\% sebelum mengikuti kegiatan dan sesudah mengikuti kegiatan naik menjadi $73 \%$ melalui pertanyaan pertama tentang tahapan yang harus dilaksanakan dalam praktik survey kepuasan pelanggan. Berdasarkan kenaikan persentase tersebut, dapat disimpulkan bahwa terdapat peningkatan pengetahuan dasar dari peserta pelatihan tentang konsep, manfaat, serta tahapan dalam praktik survey kepuasan pelanggan yang terstruktur dan terdokumentasi dengan baik.

Pertanyaan kedua berkaitan dengan pengetahuan peserta dalam hal merancang kuesioner sesuai dengan format yang dibutuhkan dalam praktik survey kepuasan pelanggan. Hasil pengolahan data pada kuesioner pretest dan posttest menunjukkan nilai sebesar 35\% sebelum mengikuti kegiatan dan sesudah mengikuti kegiatan naik menjadi 65\%. Berdasarkan kenaikan persentase tersebut, dapat disimpulkan bahwa terdapat peningkatan pengetahuan dari peserta pelatihan tentang cara menentukan secara spesifik informasi yang dibutuhkan, menentukan susunan kata dari pertanyaan, dan mengidentifikasi formulir dan layout dalam kuesioner.

Tabel 4. Respon peserta setelah pelatihan

\begin{tabular}{ccccccc}
\multicolumn{7}{c}{ (posttest) } \\
\hline Responden & \multicolumn{7}{c}{ (R) } & P1 & P2 & P3 & P4 & P5 & P6 \\
\cline { 2 - 7 } R1 & 8 & 8 & 7 & 6 & 6 & 7 \\
\hline R2 & 7 & 6 & 6 & 5 & 5 & 6 \\
\hline R3 & 7 & 6 & 6 & 5 & 5 & 7 \\
\hline R4 & 7 & 5 & 6 & 5 & 4 & 6 \\
\hline R5 & 8 & 8 & 7 & 6 & 5 & 7 \\
\hline R6 & 7 & 5 & 6 & 5 & 4 & 6 \\
\hline R7 & 8 & 8 & 6 & 6 & 5 & 7 \\
\hline R8 & 7 & 6 & 6 & 5 & 5 & 6 \\
\hline R9 & 7 & 8 & 7 & 6 & 5 & 7 \\
\hline R10 & 7 & 5 & 6 & 5 & 6 & 7 \\
\hline & & & & & &
\end{tabular}

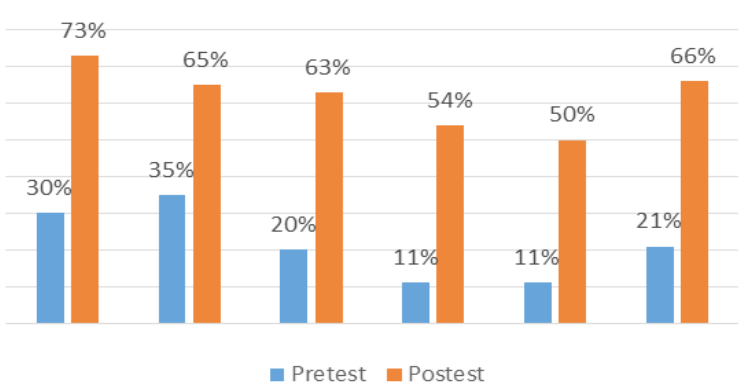

Gambar 3. Persentase tanggapan peserta sebelum kegiatan (pretest) dan sesudah kegiatan (posttest)

Warta LPM, Vol. 23, No. 2, September 2020 
Pertanyaan ketiga berkaitan dengan pengetahuan peserta dalam hal merancang prosedur sampling. Hasil pengolahan data pada kuesioner pretest dan posttest menunjukkan nilai sebesar $20 \%$ sebelum mengikuti kegiatan dan sesudah mengikuti kegiatan naik menjadi $63 \%$. Berdasarkan kenaikan persentase tersebut, dapat disimpulkan bahwa terdapat peningkatan pengetahuan dari peserta pelatihan tentang cara untuk mendefinisikan populasi sasaran, menentukan sampel, memilih teknik sampling, menentukan jumlah sampel, dan melaksanakan proses sampling.

Pertanyaan keempat berkaitan dengan pengetahuan peserta dalam hal menyiapkan data. Hasil pengolahan data pada kuesioner pretest dan posttest menunjukkan nilai sebesar $11 \%$ sebelum mengikuti kegiatan dan sesudah mengikuti kegiatan naik menjadi 54\%. Berdasarkan kenaikan persentase tersebut, dapat disimpulkan bahwa terdapat peningkatan pengetahuan dari peserta pelatihan tentang cara untuk melakukan pemeriksaan terhadap kuesioner yang telah diisi oleh responden, melakukan pengkodean, melakukan entry data, dan analisis data menggunakan software SPSS for windows.

Pertanyaan kelima berkaitan dengan pengetahuan peserta dalam hal menginterpretasikan hasil survey. Hasil pengolahan data pada kuesioner pretest dan posttest menunjukkan nilai sebesar 11\% sebelum mengikuti kegiatan dan sesudah mengikuti kegiatan naik menjadi 50\%. Berdasarkan kenaikan persentase tersebut, dapat disimpulkan bahwa terdapat peningkatan pengetahuan dari peserta pelatihan tentang cara untuk mengevaluasi hasil akhir analisis data berupa karakteristik responden dan hasil distribusi frekuensi yang diperoleh dari software SPSS for windows, dan juga melakukan rekap terhadap jawaban dari pertanyaan terbuka.

Pertanyaan keenam berkaitan dengan pengetahuan peserta dalam hal penyusunan arsip atau dokumentasi kegiatan survey kepuasan pelanggan. Hasil pengolahan data pada kuesioner pretest dan posttest menunjukkan nilai sebesar $21 \%$ sebelum mengikuti kegiatan dan sesudah mengikuti kegiatan naik menjadi $66 \%$. Berdasarkan kenaikan persentase tersebut, dapat disimpulkan bahwa terdapat peningkatan pengetahuan dari peserta pelatihan tentang cara untuk melakukan penyusunan arsip atau dokumentasi kegiatan survey kepuasan pelanggan dan menghasilkan laporan kegiatan survey kepuasan pelanggan secara mandiri.

Berdasarkan keseluruhan hasil tersebut, diketahui bahwa pada keseluruhan tahapan kegiatan skor posttest mengalami peningkatan $\geq 25 \%$ dari pada skor pretest. Pelaksanaan masing-masing tahapan kegiatan diikuti oleh 10 orang peserta. 10 orang peserta tersebut mewakili keseluruhan dari karyawan coffee shop Cekopi. Dapat disimpulkan bahwa keterlibatan pengelola coffee shop Cekopi sebagai peserta dalam kegiatan ini sebesar 100\%. Hasil akhir dari keseluruhan tahapan kegiatan ini adalah laporan survey kepuasan pelanggan UMKM coffee shop Cekopi tahun 2019. Berdasarkan indikator yang telah diukur, dapat disimpulkan bahwa kegiatan pendampingan, penyuluhan, dan pelatihan survey kepuasan pelanggan untuk mitra UMKM coffee shop Cekopi ini dinyatakan berhasil.

Berdasarkan laporan survey kepuasan pelanggan yang telah dihasilkan, pengelola coffee shop cekopi memperoleh informasi yang lebih akurat terkait dengan persepsi pelanggan terhadap kualitas pelayanan dari pegawai cekopi, persepsi pelanggan terhadap kualitas fisik (yang terdiri dari: makanan, minuman, serta interior) di cekopi, persepsi pelanggan terhadap harga yang harus dibayarkan ketika mengunjungi cekopi, serta tingkat kepuasan pelanggan cekopi secara umum. Informasi tersebut sebelum kegiatan pendampingan dilaksanakan tidak dimiliki oleh mitra, mengingat mereka belum pernah melaksanakan kegiatan survey kepuasan pelanggan secara terstruktur dan sistematis sebelumnya. Informasi ini telah memberikan gambaran yang lebih jelas bagi pengelola coffee shop cekopi untuk mengidentifikasi apa yang menjadi kebutuhan, keinginan, dan perilaku pelanggan yang dapat digunakan sebagai dasar perbaikan dan pengembangan bisnis mereka di masa mendatang.

\section{SIMPULAN}

Berdasarkan pelaksanaan kegiatan pendampingan survey kepuasan pelanggan 
untuk mitra UMKM coffee shop Cekopi oleh Tim Pengabdian Masyarakat Univet Bantara Sukoharjo, dapat disimpulkan bahwa kegiatan ini telah berjalan baik dan sesuai dengan rancangan kegiatan yang telah dirumuskan. Keberhasilan dari kegiatan ini dibuktikan dari tercapainya indikator peningkatkan pengetahuan dan pemahaman peserta pelatihan mengenai pelaksanaan survey kepuasan pelanggan yang terstruktur dan terdokumentasi dengan baik sebesar $\geq 25 \%$ melalui perbandingan tahap pretest dan posttest. Dapat disimpulkan bahwa mitra UMKM telah mengalami peningkatan pengetahuan dalam hal pelaksanaan survey kepuasan pelanggan yang terstruktur. Di samping itu, hasil akhir dari keseluruhan tahapan kegiatan ini adalah laporan survey kepuasan pelanggan UMKM coffee shop Cekopi tahun 2019. Laporan tersebut dihasilkan oleh pihak mitra UMKM berdasarkan arahan yang diberikan oleh Tim Pengabdian Masyarakat Univet Bantara Sukoharjo. Dapat disimpulkan bahwa mitra UMKM telah mengalami peningkatan pengetahuan dalam hal pengarsipan hasil kegiatan survey kepuasan pelanggan.

Saran untuk mendukung keberlanjutan kegiatan ini di masa mendatang adalah: pertama, pihak coffee shop Cekopi selaku mitra UMKM diharapkan dapat memanfaatkan hasil dari laporan survey kepuasan pelanggan untuk mendukung pengambilan keputusan bisnis di masa mendatang. Kedua, pihak coffee shop Cekopi diharapkan melaksanakan kegiatan survey kepuasan pelanggan secara mandiri dan berkala, agar dapat melakukan perbaikan secara berkelanjutan dalam praktik bisnisnya. Terakhir,pihak coffee shop Cekopi diharapkan tidak ragu untuk aktif berdiskusi dengan Tim Pengabdian Masyarakat Univet Bantara Sukoharjo apabila menemui hambatan dalam pelaksanaan survey kepuasan pelanggan secara mandiri di masa mendatang.

\section{PERSANTUNAN}

Ucapan terima kasih kami sampaikan kepada Lembaga Penelitian dan Pengabdian kepada Masyarakat (LPPM) Universitas Veteran Bangun Nusantara yang telah membantu pendanaan sehingga kegiatan dapat berjalan dengan baik. Selain itu, terima kasih juga kami sampaikan kepada pengelola coffee shop Cekopi yang turut serta membantu dan berpartisipasi sehingga kegiatan dapat berjalan dengan lancar.

\section{DAFTAR PUSTAKA}

Ariyanto. 30 Januari 2019. Cekopi, Kedai Kopi di Atas Mobil Combi. http://www.genpi.co (di akses pada tanggal 21 Maret 2019).

Astutik, Yuni. 20 Desember 2018. Es Kopi Susu di Solo Mulai Rp12.000, Rasa Nikmat dengan Harga Bersahabat. http://www.travelingyuk.com (di akses pada tanggal 21 Maret 2019).

Cekopi. 2019. Data Penjualan Cekopi Januari - Desember 2018. Tidak dipublikasikan.

Ferdinand, Augusty. 2014. Metode Penelitian Manajemen: Pedoman Penelitian untuk Penulisan Skripsi, Tesis dan Disertasi Ilmu Manajemen. Badan Penerbit Universitas Diponegoro. Semarang.

Kristin, F. (2017). Keberhasilan Belajar Mahasiswa Ditinjau Dari Keaktifan Dalam Perkuliahan Dengan Menggunakan Pembelajaran Active Learning. JURNAL PENDIDIKAN DASAR PERKHASA: Jurnal Penelitian Pendidikan Dasar, 3(2), 405-413.

Kotler, Philip \& Armstrong, Gary. 2014. Prinsip-Prinsip Pemasaran. Edisi 14, Jilid 1. Jakarta: Erlangga.

Kotler, Philip \& Keller, K.L., 2016. Marketing Management. $15^{\text {th }}$ Edition. New Jersey: Prentice Hall International, Inc.

Kumalaningrum, F., Widajanti, E., Sutarno. 2016. Analisis Pengaruh Kualitas Pelayanan Terhadap Loyalitas Konsumen dengan Kepuasan Konsumen Sebagai Variabel Moderasi (Studi pada Konsumen CS Kopi Tubruk Surakarta). Jurnal Ekonomi dan Kewirausahaan Vol. 16 No. 2 Juni 2016: $226-233$. 
Insani, dkk - Pendampingan Pelaksanaan Survey Kepuasan Pelanggan ...

Munandar, Dadang. 2016. Relationship Marketing: Strategi Menciptakan Keunggulan Bersaing. Yogyakarta: Ekuilibria.

Sekaran, Uma \& Bougie, R. 2017. Metode Penelitian untuk Bisnis: Pendekatan Pengembangan-Keahlian. Jakarta: Salemba Empat.

Sugiyono. 2017. Metode Penelitian Kuantitatif, Kualitatif, dan R\&D. Bandung: Alfabeta.

Sukirman, Putra, M.M. R., \& Kusumawati, A.J. 2019. Optimalisasi Penggunaan Aplikasi Cloud Computing Sebagai Sarana Pengelolaan Kuesioner Bagi Guru Muhammadiyah Tanon. Jurnal Warta Lembaga Pengabdian pada Masyarakat Vol. 22, No. 2, September 2019, hlm. 120-128.

Wibowo, A.P. 2018. Perencanaan Sistem Persediaan Bahan Baku Guna Meningkatkan Efisiensi pada Coffee Shop Cekopi Solo. Skripsi S1 Reguler Fakultas Ekonomi dan Bisnis Islam Institut Agama Islam Negeri Surakarta. Tidak dipublikasikan. 